\title{
Reduction of NO Emission from Gas TURBINE COMBUSTOR Applying Fuel-Staged Combustion
}

\author{
Mohammad Nazri Mohd. Jaafar \\ Department of Aeronautics and Automotive, Mechanical Engineering Faculty \\ Universiti Teknologi Malaysia, 81310 UTM Skudai, JOHOR, Malaysia \\ Fax: 607-5566159, Email: nazri@fkm.utm.my
}

\begin{abstract}
A two-stage lean/lean gas turbine combustor was developed with low $\mathrm{NO}_{x}$ characteristics in each stage using a small radial swirler of $40-\mathrm{mm}$ outlet diameter in the pilot stage. Both flame tubes were arranged in series with the smaller combustor ( $76 \mathrm{~mm}$ inside diameter) as the pilot stage and the larger combustor (140 $\mathrm{mm}$ inside diameter) as the main stage. The pilot stage was fuelled via vane passage fuel injector, while the main stage was fuelled around the wall of the exit plane of the pilot stage, using wall fuel injectors.

Low $\mathrm{NO}_{\mathrm{x}}$ emissions were obtained when using fuel staging for methane fuel, as low as $6 \mathrm{ppm}$. A NO reduction of more than $40 \%$ was obtained at equivalence ratio of near 0.7 , when using fuel staging compared to the non-fuel-staging test. Tests were conducted using methane as fuel. This was achieved at very small increase in carbon monoxide emissions especially near the rich region and with almost no increase at all in the unburned hydrocarbon emissions at the same equivalence ratio.
\end{abstract}

Keywords: NOx emissions, fuel staging, carbon monoxide, swirler.

\section{INTRODUCTION}

The effects of increased levels of $\mathrm{NO}_{\mathrm{x}}$ in the atmosphere are wide reaching. In the atmosphere, $\mathrm{NO}$ is rapidly oxidized to $\mathrm{NO}_{2}$ and in this form, plays an essential role in the formation of tropospheric ozone and photochemical smog. It is oxidized to form nitric acid that may then be deposited as acid rain [1]. At ground level, increased concentrations (above $0.06 \mathrm{ppm}$ ) of $\mathrm{NO}_{2}$ can cause respiratory problems [2].

The legislation of $\mathrm{NO}_{x}$ emission limits in many parts of the world has substantially complicated the process of combustor design. Attempts at lowering $\mathrm{NO}_{\mathrm{x}}$ emissions by reducing the flame temperature will lead to reduced flame stability or increased $\mathrm{CO}$ emissions. Unacceptable stability problems or $\mathrm{CO}$ emissions always limit the lowest NOx emission obtainable in a given configuration. Thus, the combustor design has become a trial-and-error, multi-parameter optimization process [3].

Basically there are two techniques of controlling $\mathrm{NO}_{x}$ : those which prevent the formation of nitric oxide (NO) and those which destroy NO from the products of combustion. In the present work both methods are employed: lean combustion for low thermal $\mathrm{NO}_{x}$ followed by second stage fuel injection for combustion in the combustion products of the lean zone, which can destroy first stage $\mathrm{NO}_{\mathrm{x}}$ through a reburn mechanism.

The methods that prevent the formation of NO involved modifications to the conventional combustor designs or operating conditions, such as lean primary zone, rich primary zone, rich/lean, 


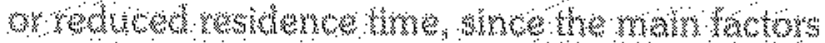

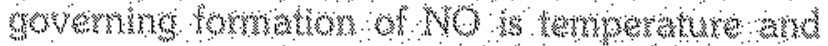

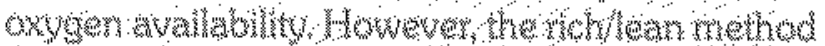

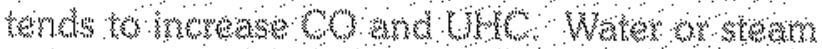

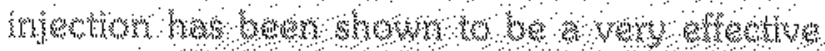

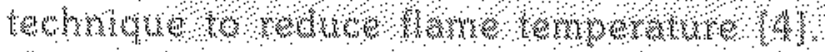

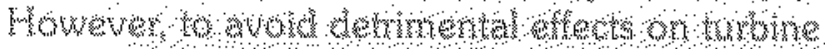

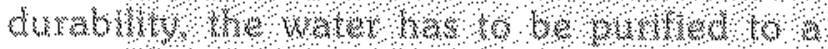

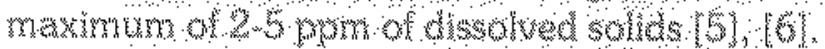

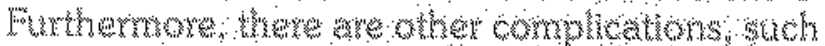

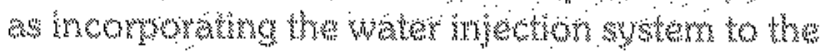

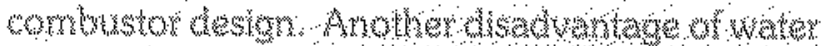

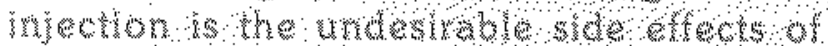

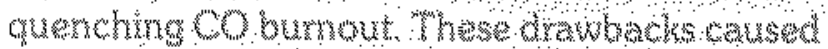

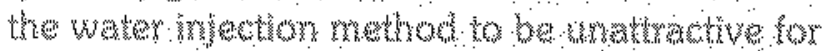

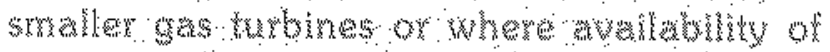

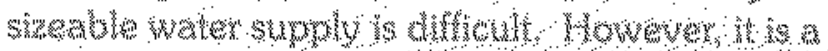

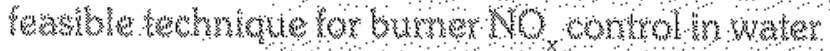

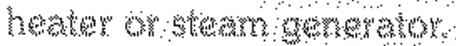

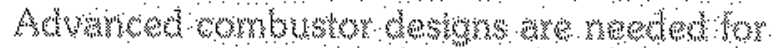

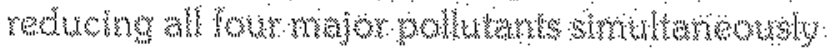

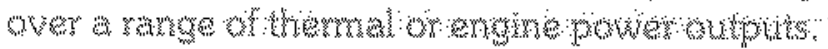

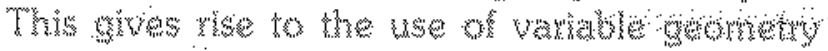

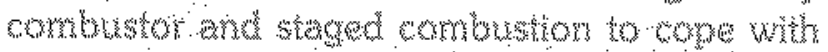

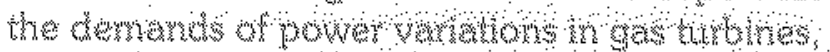

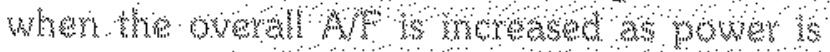

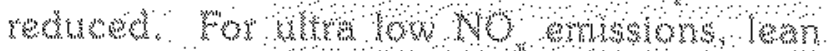

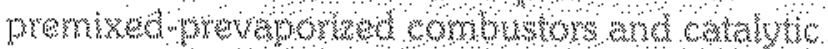

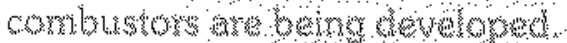

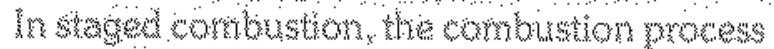

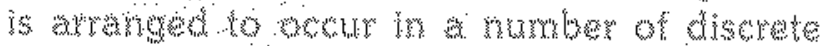

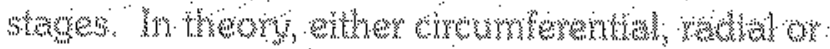

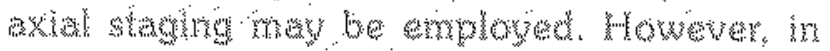

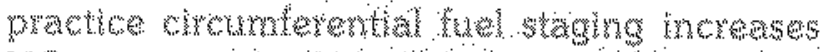

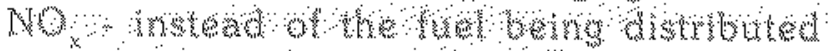

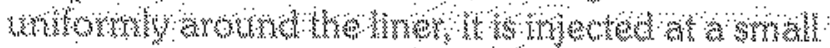

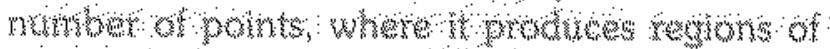

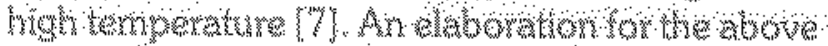

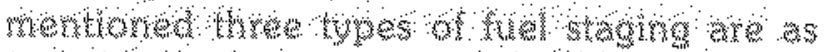

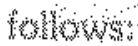

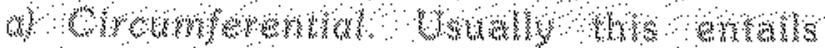

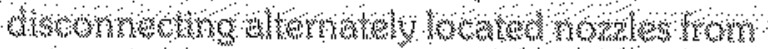

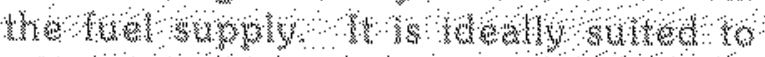

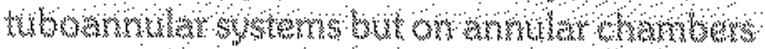

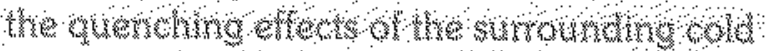

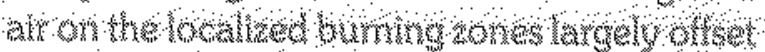
wawandwes

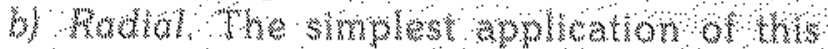

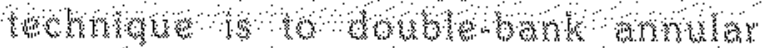

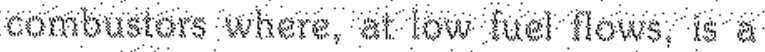

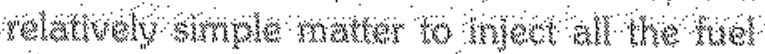

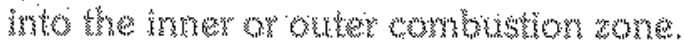

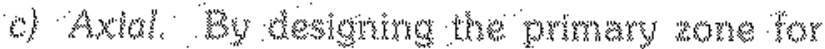

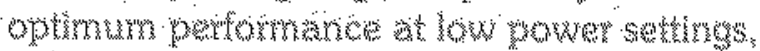

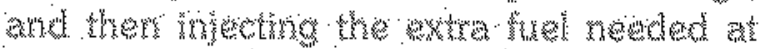

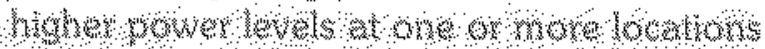

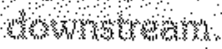

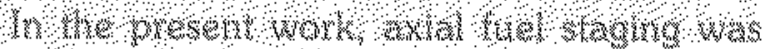

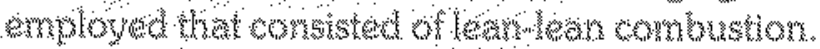

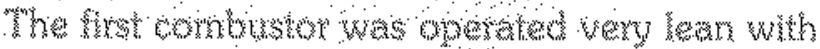

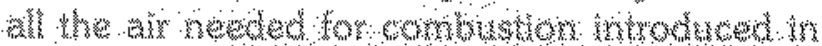

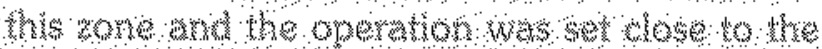

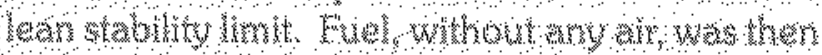

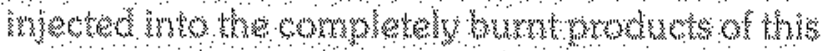
lear momary combuswon zone to bxing the combustor to the dexired overall excess ain.

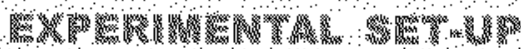

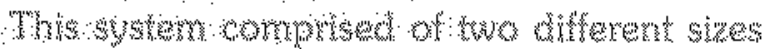

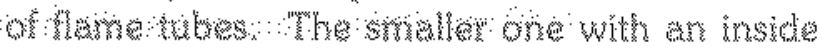

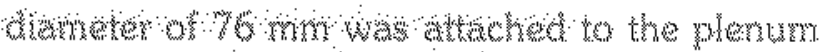

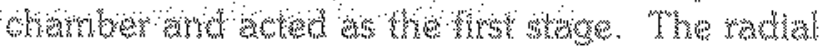

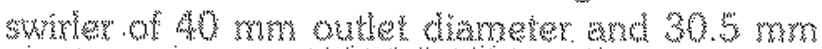

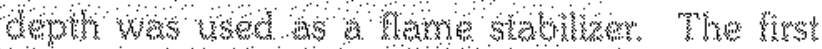

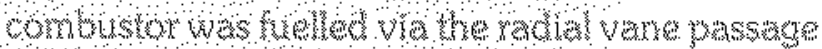

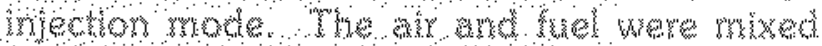

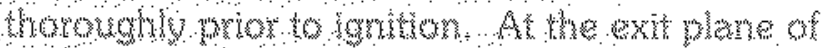

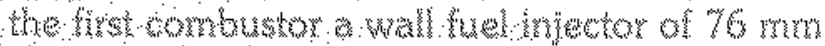

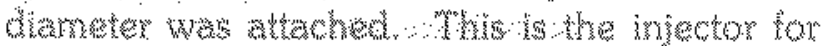

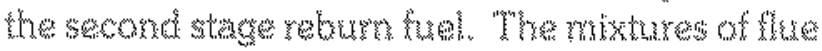

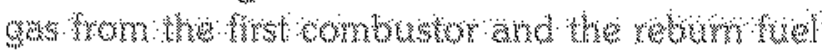

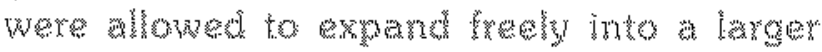

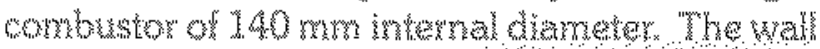

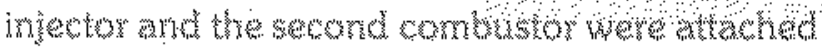

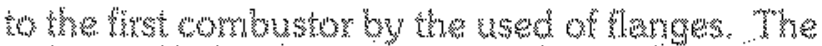

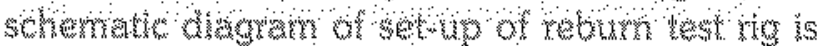

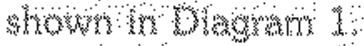

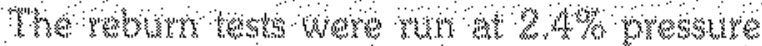

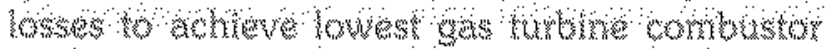

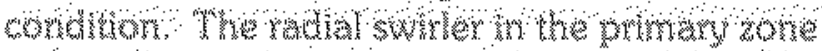

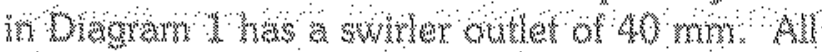

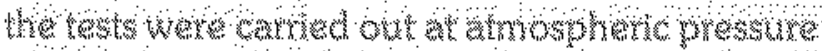

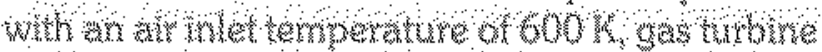

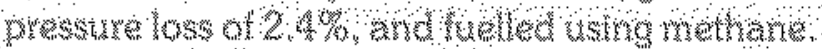

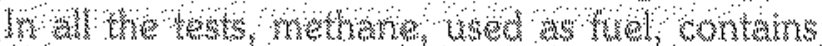

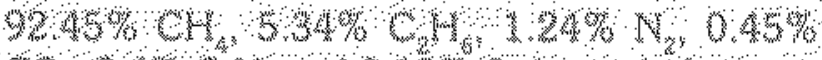

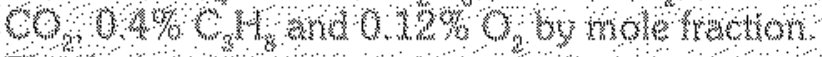

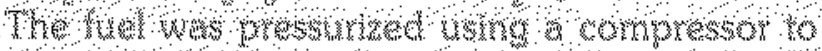

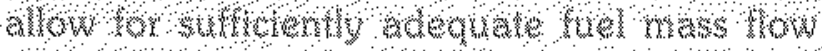

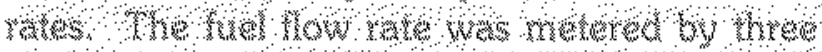




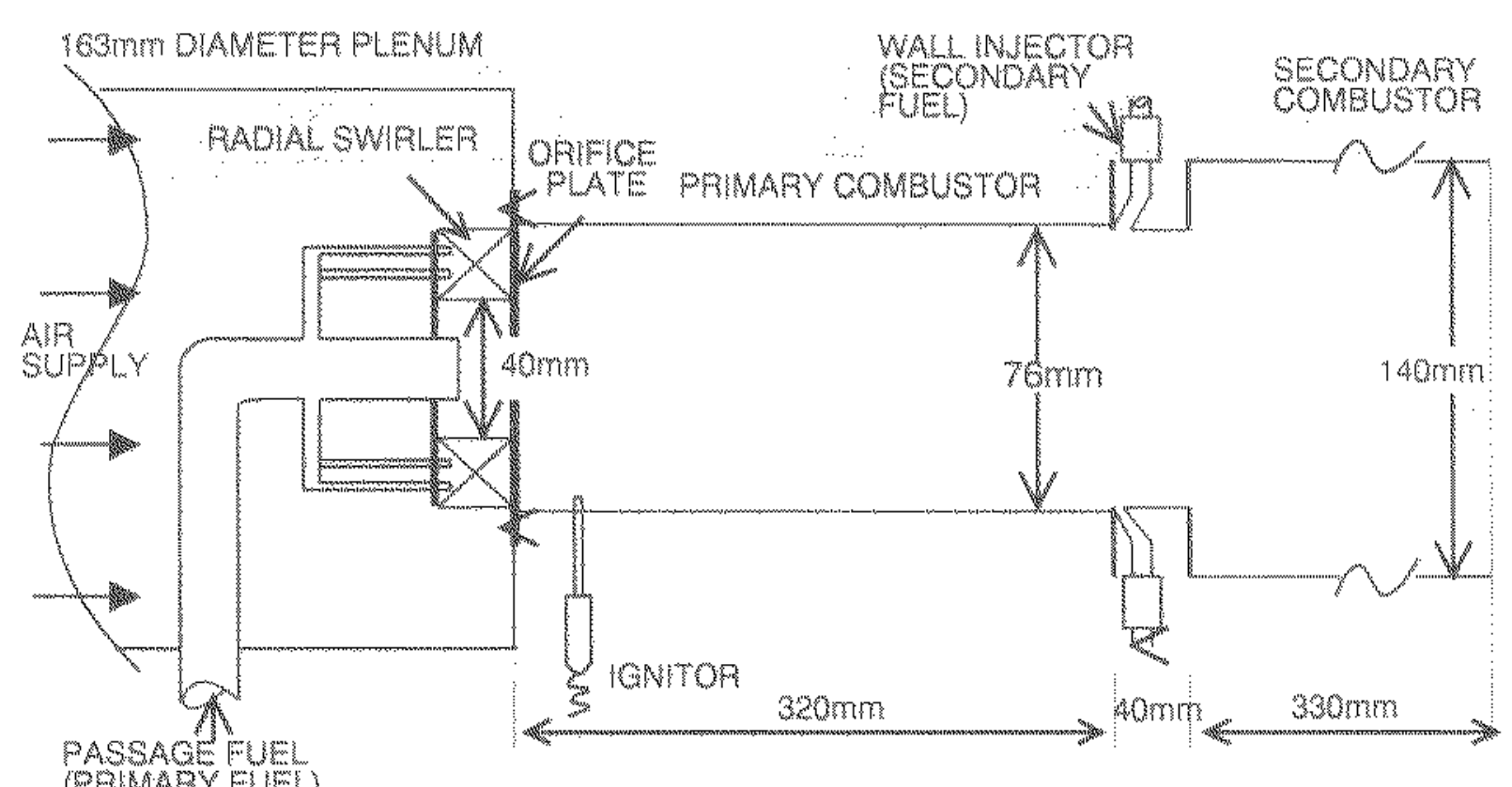

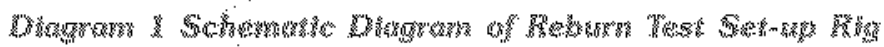

GECM Marconi seres 2000 rotameters with a

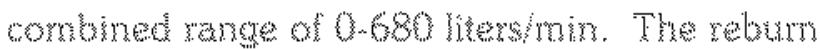
tuel was metered using and and range rotameter of 2.5 .22 Mters/min manuratured by KDO Mopmey Series 2000 .

There were wo sustems of surplying air for diferent arr requirements: ane of which bised an air blows and the other used the laboratery compresued aim supply. The higher volume

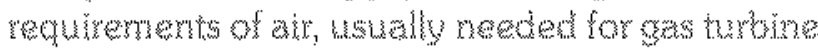

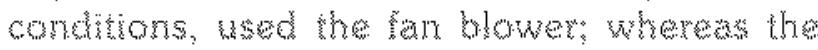

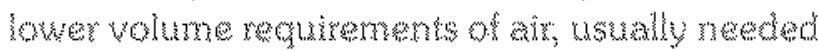

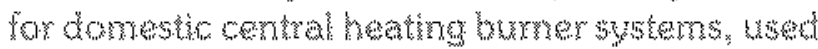
the commersed aly supply from the laboratory.

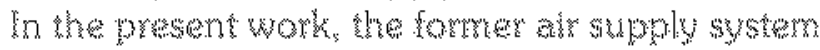
was adopted.

The compressed air was passed through a variable area liow meter. A pressume tapping was used to monitor the molnt statio pressure to the

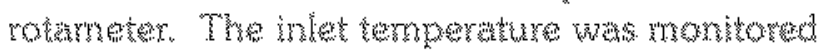

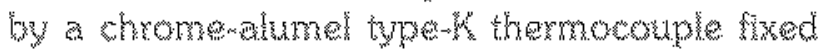
bewern the rotameter and the control walve. "The

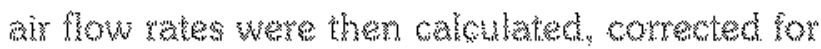
inter tempexwre and pressure deviation from the rotameter calibration values of $150 \mathrm{~cm}$ and $760 \mathrm{~mm}$ mercury baxmetric pressure.

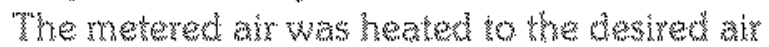

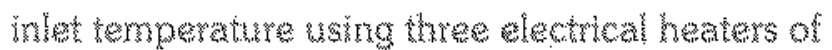
3 wW each that were arranged in series totalng wh to $9 \mathrm{~kW}$ of heat. In this case, the proheat tamperature is $600 \mathrm{~K}$. The heater lements were comected the air supply plewm chamber by a go connector. "he heats and the plenum chamber connewed to the combustor were

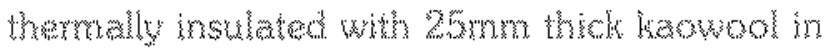
onder to prevent heav losses. The insutater section also were covered with a rellecting fol

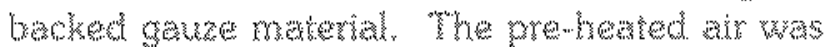

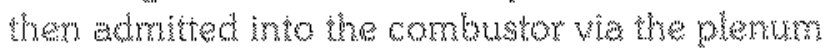

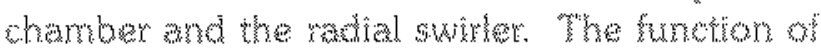

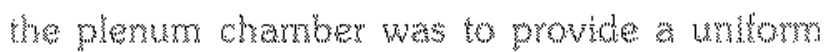

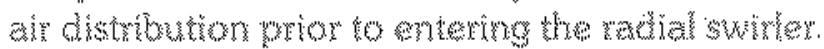

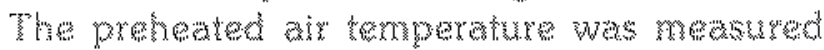

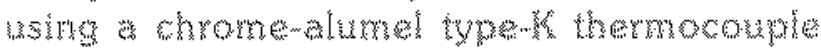
positioned on the central axis and lonmm upstrem of the combuston indet phane. The inlet static pressure of the combustro was rneasured using four statio pressure wappings whth the same mantold positomed 1 summ upstrean of the combuster inter pland.

The eshaxus gas was samplack contrinously by

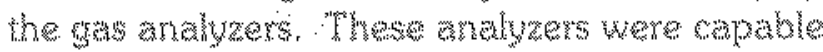
of a complete ond the spot andysis of $\mathrm{CO}$, UHC, $\mathrm{CO}, \mathrm{NO}, \mathrm{NO}_{2}$ and $\mathrm{O}_{2}$. The samplire systern was designed and constructed to ensure hat a

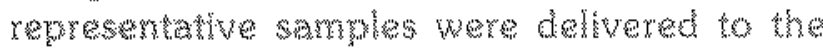
varions instruments.

Am "X's contigumaton gas sampling probe wh 40 holes on centre of equal areas was used for

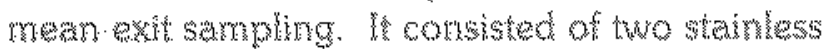

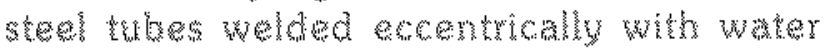
circuling in batween the whes to cool the 


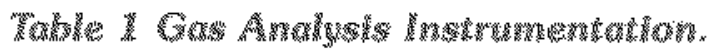

\begin{tabular}{|c|c|c|c|}
\hline Gas Component & Method of Analysis & Reading Ranges & Manguacturer \\
\hline $\mathrm{CO}_{2}$ & $\begin{array}{l}\text { Nonndispersive } \\
\text { Infram-ked }\end{array}$ & $\begin{array}{l}\text { 4 ravger } \\
0.0 .1 \% \\
0-15 \%\end{array}$ & $A D . C$ \\
\hline 60 & $\begin{array}{l}\text { Non-Dispersive } \\
\text { Infra-Red }\end{array}$ & 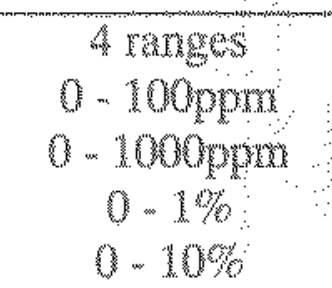 & A.D.C. \\
\hline UHC & Flame Ion Detection & $\begin{array}{c}7 \text { ranges } \\
0.100 \text { ppm } \\
0-10 \%\end{array}$ & Signal Instrument \\
\hline NO/NO & $\begin{array}{l}\text { Chemiluminescent } \\
\text { (Carbon Converter) }\end{array}$ & $\begin{array}{c}7 \text { ranges } \\
0.4 p p m \\
0.400 p p m\end{array}$ & B.O.C. Duminox \\
\hline $\mathrm{O}_{2}$ & pramagnetic & $0 \cdot 100 \%$ & $\begin{array}{l}\text { Taylor Instrument } \\
\text { Servomex }\end{array}$ \\
\hline
\end{tabular}

exhaust gases and the probes. The sample weds

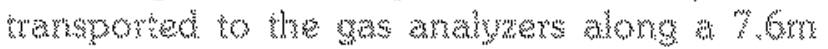
heated helon sample whe to be andysed ar $\mathrm{Co}$.

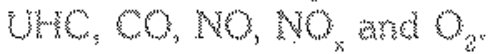

"he sample gas from the combustor was pumper into the oven to draw sarnples to the

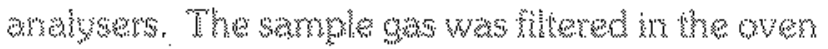

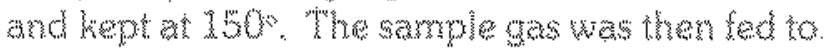

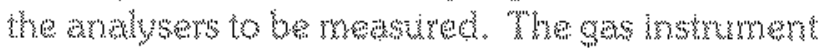
used and their detrion rarges are summerised in wable

The gas was andyed for co and $\mathrm{CO}_{2}$ wath

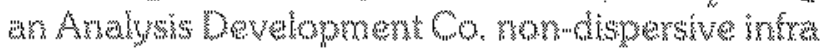

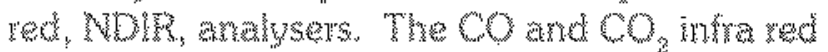
andysars had wo cells and wo electrical

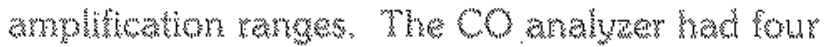

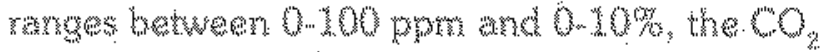
andyrer also hat four ranges but. these were

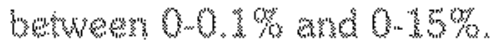

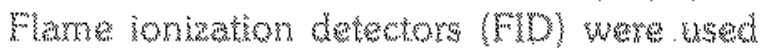
to racasure by brocarbon (UHC) woncentraton in the sample gas we for the thame in the FD was contail of 60 preverthydrogen and 40 percent

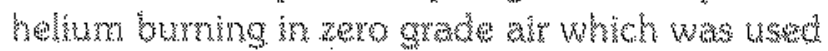
to reduce the rerrivity of the Fud responses to the

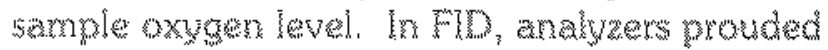

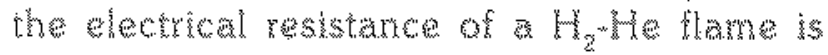

monitored ard when sample ger thet contains

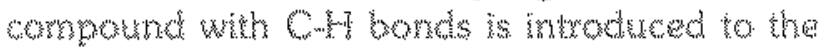

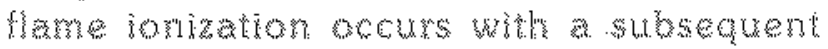
reduction in the resistance of the frame. The

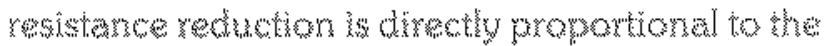

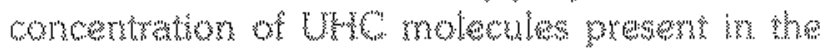
sample gas thet in introduced to the lawe. To

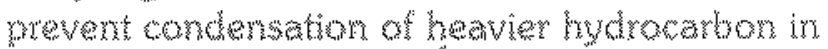
the sample gas he sample gas lines po the Fid andusere are kept werat at $150 \mathrm{C}$.

The oxygen concentration in the smoluges was reasured by a Servomex paramande

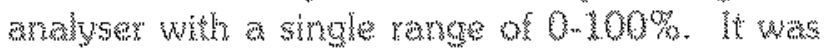
powered by sath-contuined bateries. Oxysen has the propery of being paramagnetic due to the molecules unpared electrons. The aralyer.

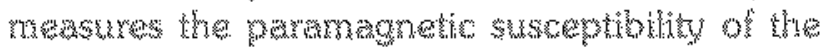
sample sas wht oxygen content by means of a proven magneto-gunaric tyoe mezsurng cell.

The No errissions in whe sarnple gras were

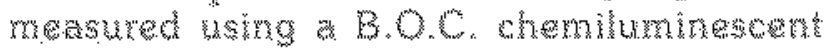

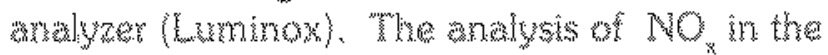
sample on is based on the ermission of light

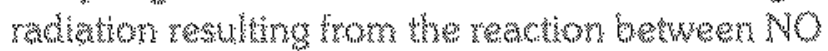
and $O_{3}$. The intersing of the hight emited is measured by photon detector and a proporional to $\mathrm{NO}$ concentration. A carbonmolybotenum 


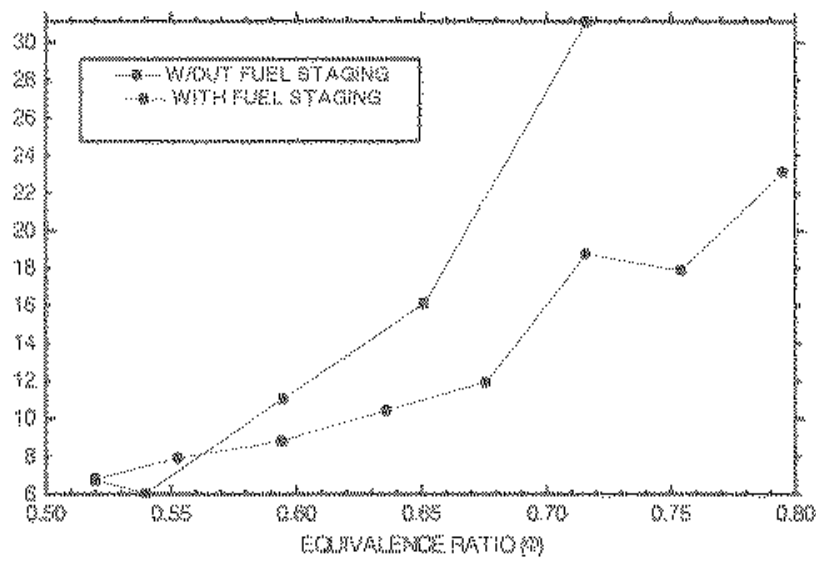

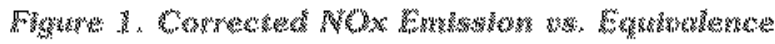

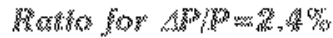

converter was used to convert $\mathrm{NO}_{2}$, row the sample gas to $\mathrm{NO}$ ahear of the reentom thamber

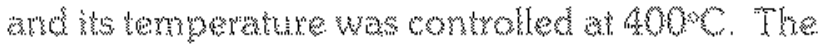
azone was generated from zevo grade ail from the air purficatom systern (ADS). The ar purfier was manufacured by Signat Instrments Control.

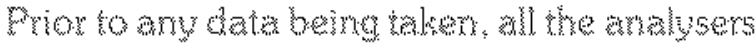
had to be caltbrated. The aralysers were

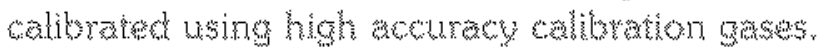

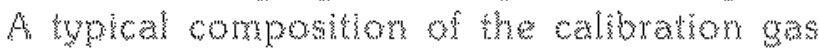

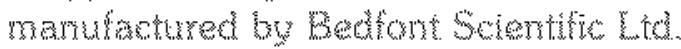

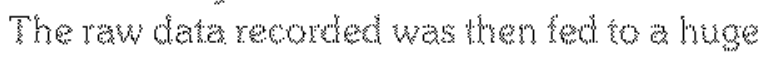
computer propramme

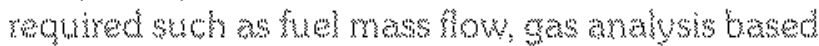

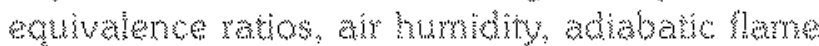
temperature, combustion indficiency, and corrected No miscioms.

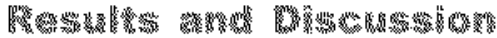

Figures I-4 show the plots of corrected $\mathrm{NO}_{x}$

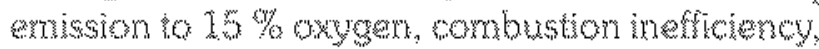
carbon monoxide and unburred hydrocabon missions plotted against operating equivalence ratios.

The genaral trend can be seen that by applying

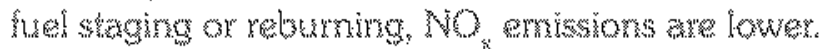

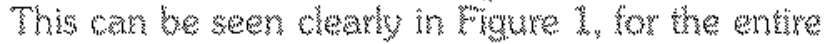
range of operating equivalene ratios. However, on the leaner side, le. at lower equivelence ratios,

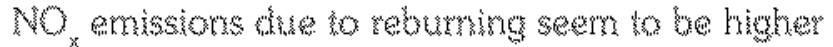
than that when not applying fuel staging. "Were is no logical explanation for this phenomeron, but an

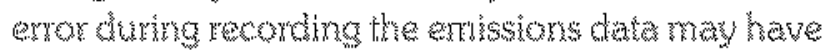
caused this problerm.

A corrected No, mission of lower than $20 \mathrm{pm}$ was achieved at cquivalence ratio of 0.7 when using

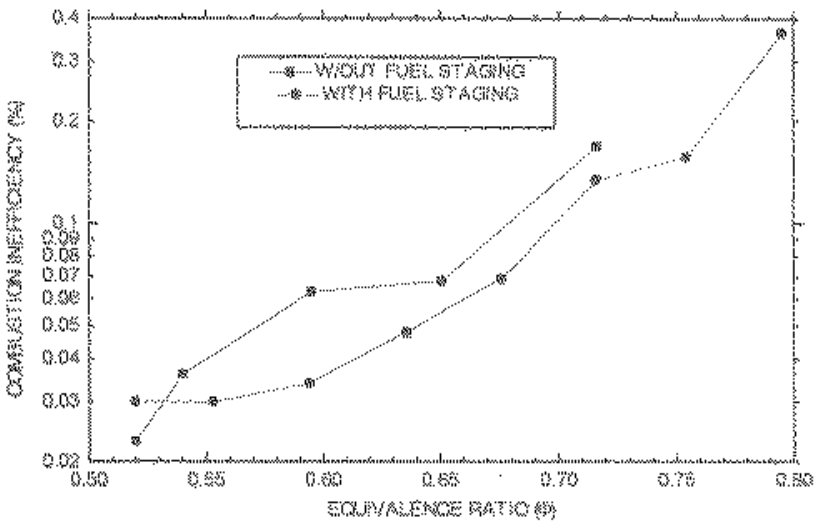

F"

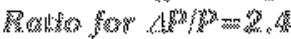

fuel staging. Utratow $\mathrm{NO}$ of 6 pom was also achieved at the leanest condition. No reductom

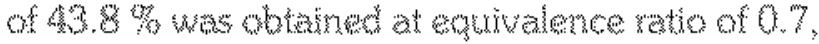
When using fulet staging compared to the non staging tests.

From Figure 2, agan, the gereral trend was

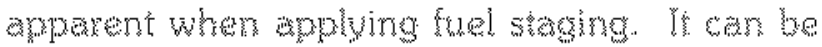
seen that when applying fuel staging the

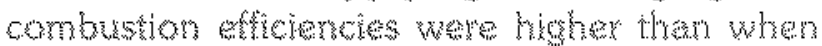
not applyng fuet staging over the entre ramge of operating arvivience ratos. Combuston eftriencies of greater than $99.9 \%$ were achewer wh to mear 0.7 equivalence ratos molyng the very good mixing of the fuel and air prior to ignitich mals alcheved. This can be atributed to the

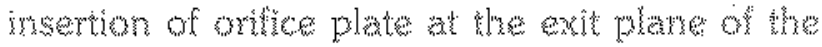
radial swinler.

Even for carbon monoxide (OO) exrows

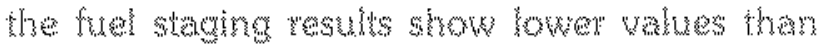
when rot applying fuel staking (Figure 3), "This a very good indication since nomally, any

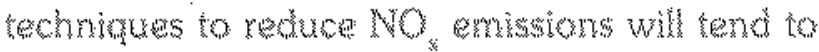
increase Co. Howeven, the prestent work is is found thet even co emiswons were reduced when applying wel stacing.

Figure 3 shows $\mathrm{CO}$ whishon of less than 100 ppm and was obtaned over whe range of equivalene ratios up to 0.67 . This is very close to the condithn without fuel staging. However, fuel staging wereses the or emissions higher

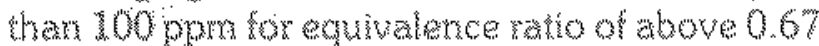
dise vo the loweresidence rime whth rebum and the lowew oxyen avatubitity.

Unburner hyormaron (UHC) emissions were also lower whan applying fuel staning comparied to that when not using fue staging. This was acheved over a wide range of operating 


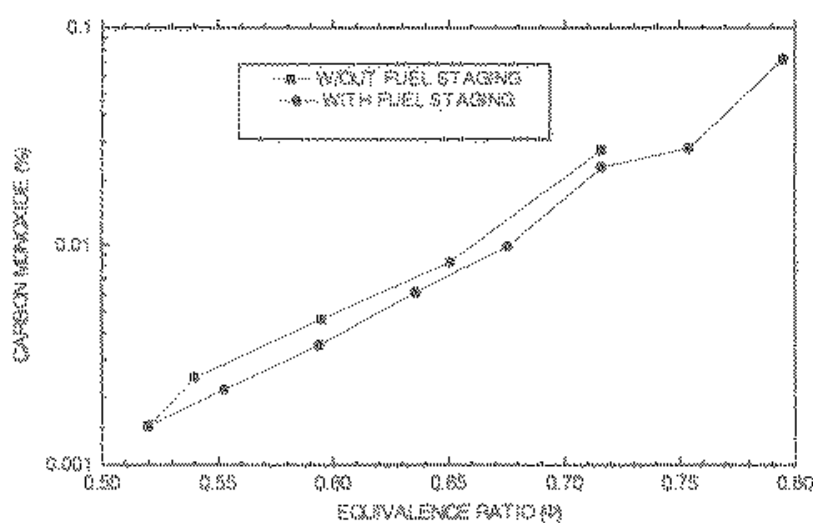

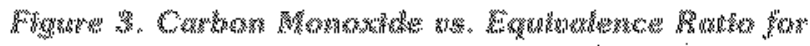

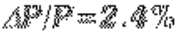

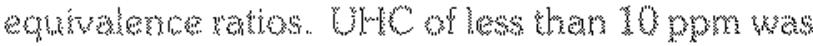
achinged tow the entre rame of operating

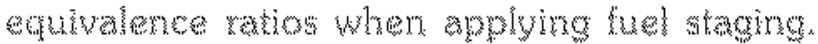

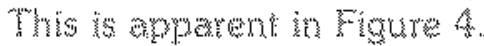

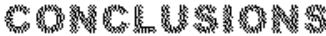

A No, reduction of more than $40 \%$ covil be

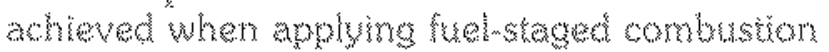
What very lear primary zone. Very good combuston etretencis were also obtumed whth

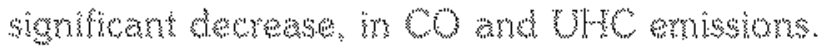

\section{W.}

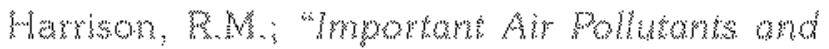

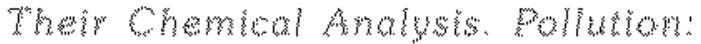
Couses, Ebrots and Conrol" Foyal Soctery of Chemistry, Londom, 1990

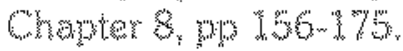

World Heath Organtistion, "Air Quahy

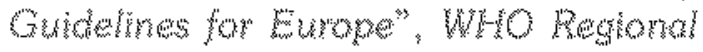

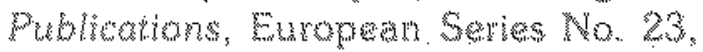
WSN 92800 1214. WMO Regional Otwee bor Furope: Copenhagen, 1987.

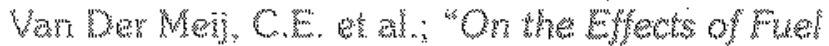
Lakage on co Producton From Mousehold Bumerg as Reveded by LfF

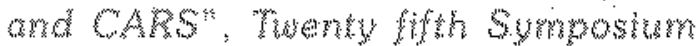
(Intermationaly on combuston, the

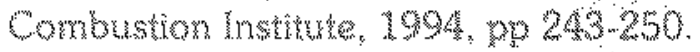

Shew H. "The Efferts of Woter, Wressure, and Equivalence Rate on Nimic Oxide Prowucion in Gos Turbines", Transwenchen of he ASME, roumul of Enginewing for cas hubines and pouser, pp. 240.246 , why 1974

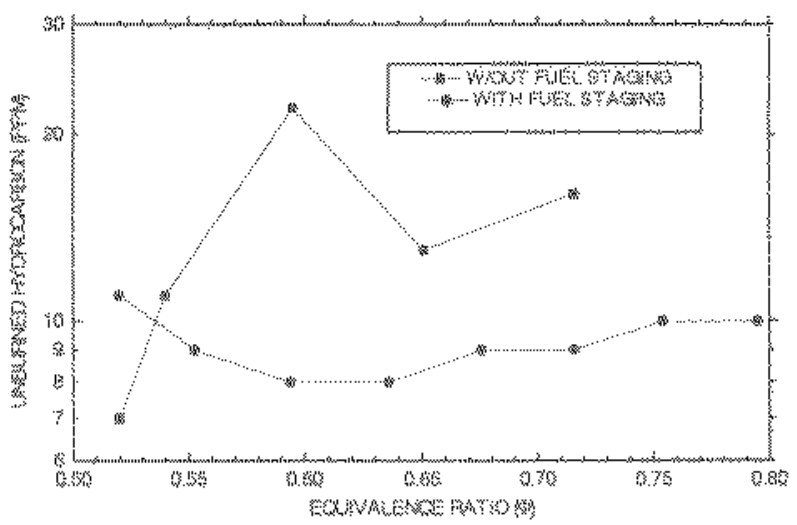

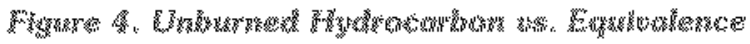

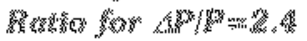

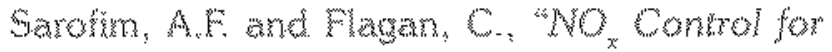
Statonary Combuston Solmegs". Prog. Energy Combustion Scienow Vol. 2, pp. L.25, pergarnon pess, 1976 .

Corre, SM., "A Revien of No formation Under cos.mubine Combution Condtions":

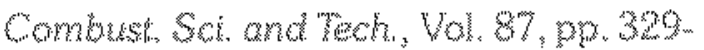
362,1992

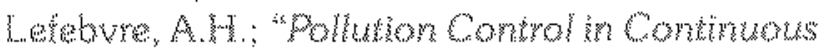

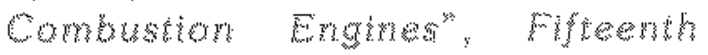

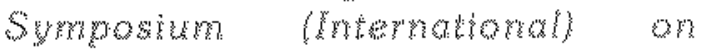
Combuston, The Combuston hrotute. 1975, py 1491180 . 